\title{
Comparative study of the hygienic behavior of Carniolan and Africanized honey bees directed towards grouped versus isolated dead brood cells
}

\author{
K.P. Gramacho ${ }^{1}$ and L.S. Gonçalves ${ }^{2}$ \\ ${ }^{1}$ Curso de Ciências Biológicas, Faculdade de Ciências e Tecnologia de Salvador, \\ Salvador, BA, Brasil \\ ${ }^{2}$ Departamento de Biologia, Faculdade de Filosofia, Ciências e Letras de \\ Ribeirão Preto, Universidade de São Paulo, Ribeirão Preto, SP, Brasil \\ Corresponding author: Kátia P. Gramacho \\ E-mail: gramacho.ssa@ftc.br; katholausa@hotmail.com
}

Genet. Mol. Res. 8 (2): 744-750 (2009)

Received December 12, 2008

Accepted January 26, 2009

Published June 30, 2009

\begin{abstract}
In Apis mellifera, hygienic behavior involves recognition and removal of sick, damaged or dead brood from capped cells. We investigated whether bees react in the same way to grouped versus isolated damaged capped brood cells. Three colonies of wild-type Africanized honey bees and three colonies of Carniolan honey bees were used for this investigation. Capped worker brood cells aged 12 to 14 days old were perforated with the pin-killing method. After making holes in the brood cells, the combs were placed back into the hives; $24 \mathrm{~h}$ later the number of cleaned cells was recorded in areas with pin-killed and control brood cells. Four repetitions were made in each colony. Isolated cells were more frequently cleaned than grouped cells, though variance analysis showed no significant difference $(\mathrm{P}=0.1421)$. Carniolan bees also were somewhat, though not significantly more hygienic than Africanized honey bees $(\mathrm{P}=0.0840)$. We conclude that honey bees can detect and remove both isolated and grouped dead brood. The tendency towards greater hygienic efficiency directed towards grouped
\end{abstract}


pin-killed brood may be a consequence of a greater concentration of volatiles emanating from the wounds in the dead pupae.

Key words: Hygienic behavior; Pin-killing method; Body fluid; Africanized honey bees; Carniolan honey bees; Apis mellifera

\section{INTRODUCTION}

Hygienic behavior in Apis mellifera consists of the removal of killed, sick or damaged brood from the brood nest by the workers. This behavior is important for the population dynamics of these bees because it can retard or avoid the development of diseases in the bee colony. One of the methods used for evaluation of hygienic behavior is perforation of the brood (pin-killing method). Through this method, the brood is damaged or killed with an insect pin, which is used to pierce the sealed brood cells through the center of the cell cap, penetrating the body of the pupa. This injury provokes removal of the damaged or dead brood by hygienic worker bees. According to Rothenbuhler (1964a,b), hygienic behavior is genetically controlled by two pairs of recessive genes, which in homozygosis allow the bees to identify the sick or killed brood inside the capped cells and remove them. The bees that execute this behavior are considered to be hygienic bees. In spite of the pioneering scientific contribution of Rothenbuhler $(1964 \mathrm{a}, \mathrm{b})$ and other scientific contributions on the same theme (Trump et al., 1967; Message, 1979; Message and Gonçalves, 1980; Milne, 1983, 1983a,b, 1985a,b; Newton and Ostasiewsky, 1986; Gilliam et al., 1983, 1989; Spivak and Gilliam, 1993; Gramacho, 1995; Gramacho and Gonçalves, 1994, 1996; Spivak and Downey, 1998; Gramacho, 2004), it is still not clear what mechanisms (physical factors, chemical factors) are responsible for the identification and removal of sick, damaged or dead brood inside the cells or how the bees proceed with the removal of the brood. As part of our effort to better understand the details of this behavior, we examined whether grouped dead capped brood (perforated worker brood cells within a small area in the comb) and isolated dead capped brood (separated perforated brood cells) are equally affected by honey bee hygienic behavior.

\section{MATERIAL AND METHODS}

This experiment was carried out in the apiary of the Department of Genetics, University of São Paulo, Ribeirão Preto Campus, Brazil. Three colonies of wild-type Africanized honey bees (a predominantly African (Apis mellifera scutellata) polyhybrid that includes less than 10\% European Apis mellifera) and three colonies of Carniolan bees (Apis mellifera carnica), descendants of mated queens of the Experimental Apiary of the University of Hohenheim, Germany, were used. The experiment was repeated four times. For evaluation of the hygienic behavior the methodology of perforation of brood cells was used (pin-killing method), based on Newton and Ostasiewsky (1986), modified by Gramacho and Gonçalves (1994). Combs containing capped worker brood cells aged 10 to 14 days old were taken from each colony. In this comb, an area containing about 100 capped worker brood cells was delimited and divided into two equal areas of about 50 cells (side A of the experimental comb). In the first (Figure 1A), about 50 capped worker brood cells were perforated (grouped cells) with a number 2 insect pin and in the second (Figure 1B), about 50 capped worker brood cells were left without perforating, as a control. On the opposite side 
of the experimental comb (side B) in an area also of capped worker brood cells, 50 randomly distributed isolated brood cells were individually perforated.
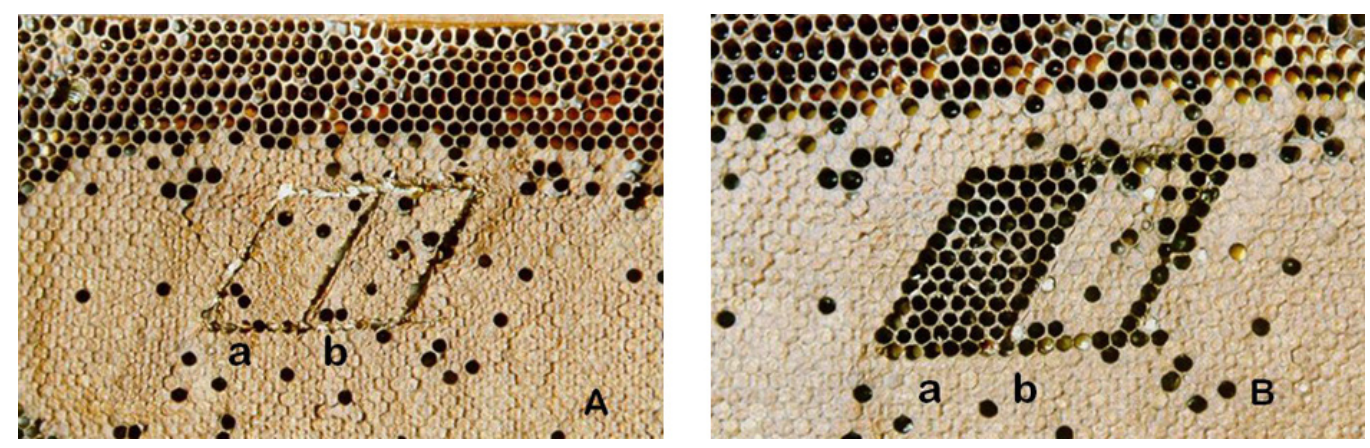

Figure 1. A. Comb with capped worker brood cells of Africanized honey bees used for the hygienic behavior test shows an area with about 100 grouped capped worker brood cells distributed in two identical (lozenge shaped) areas, with 50 cells each. The lozenge to the left (a) consists of grouped brood cells that were perforated with an insect pin and the lozenge to the right (b) presents control (not perforated) grouped brood cells. B. Results of the hygienic behavior test made with Africanized honey bees $24 \mathrm{~h}$ after pin killing the grouped capped worker brood cells. The lozenge to the left (a) contains all the pin-killed brood that was already uncapped and the brood removed by the hygienic honey bees. The lozenge to the right (b) shows the control grouped worker brood cells still capped after $24 \mathrm{~h}$.

For each comb cell containing pin-killed brood on side B, a neighboring capped brood cell was marked as a control. Both perforated and control cells were mapped for identification. After perforation of the cells the combs were placed back into the hives; $24 \mathrm{~h}$ later the cleaned cells were registered and the results compared with the control. Colored pins were placed to the left of each perforated worker brood cell with the objective of identifying, after $24 \mathrm{~h}$, the isolated cells (Figure 2A and B). For the statistical analysis the data in percent were transformed via arc-sine for comparisons by analysis of variance (SAS Institute, 1995).
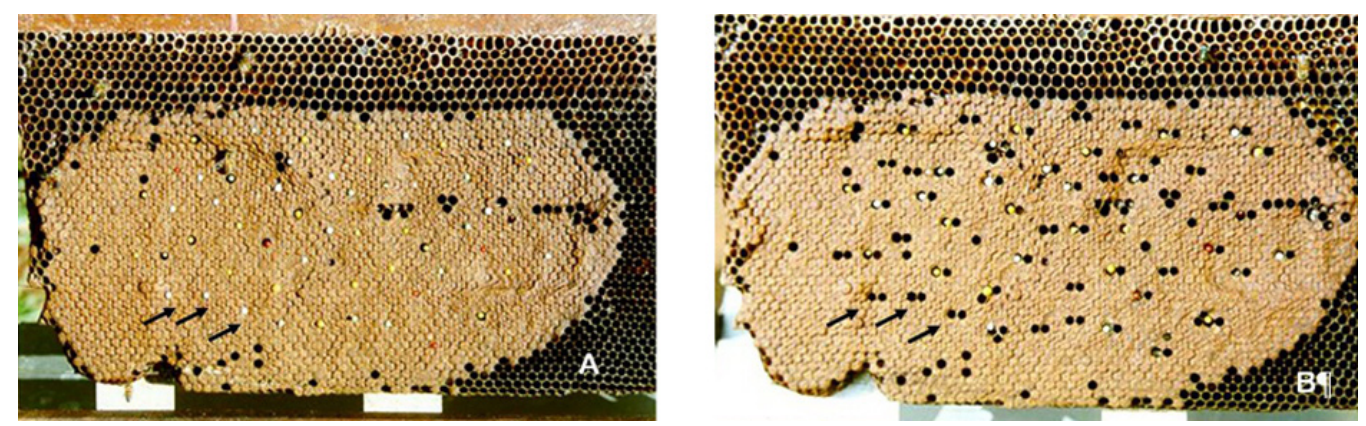

Figure 2. A. Comb of capped worker brood cells of Africanized honey bees with isolated brood cells that were perforated separately with an insect pin. A colored pin was placed to the left of each perforated cell to facilitate the localization of the perforated worker brood cells in the comb. B. Results of the hygienic behavior test $24 \mathrm{~h}$ after the perforation of the isolated capped worker brood cells. The perforated worker brood cells were uncapped and the brood removed by the hygienic honey bees within $24 \mathrm{~h}$. In some cases the hygienic bees even removed the insect pins (see arrows pointing to uncapped cells near which the colored insect pins had been removed). 


\section{RESULTS AND DISCUSSION}

The method of perforation of brood with an insect pin used in the studies of the hygienic behavior usually causes liberation, from the damaged brood, of body fluids that come out through the hole made by the pining in the worker brood cell capping. Some volatile substances also come out. Gramacho et al. (1999) observed that liberation of body fluid is not the main factor that causes removal of the damaged brood; though it certainly influences the rate of brood removal, as also found by Spivak and Downey (1998), who tested the effect of hemolymph from live pupae and from dead frozen pupae of Italian bees. Consequently, we can suppose that the removal rate of damaged brood would be proportional to the concentration of body fluid liberated in that area of the comb. It is possible that a greater liberation of body fluid from grouped damaged cells would also result in a larger concentration of volatile substances and that this would provoke a greater rate of removal of damaged brood by the hygienic bees. It is clear from these published reports that hygienic bees are able to identify damaged or dead brood and remove them from the brood comb cells. However, the factors that allow the identification and promote the removal of the damaged brood by hygienic bees have not been established. The expression of hygienic behavior is highly influenced by environmental factors (temperature, humidity, comb condition, nectar flow, etc.), chemical factors (pheromones, dead brood odors, parasitic mite odors, etc.), physical factors (movements, vibration, light, etc.) as well as by interaction between all these factors (Gramacho et al., 1998; Gramacho, 1999).

Studies have been done on various aspects of hygienic behavior in honey bees. The hypothesis that has been made is that olfactory cues trigger detection of abnormal brood within a wax-capped cell; this elicits perforation and uncapping of the cell, and removal of the cell contents. We have found that hygienic bees can detect the odor of diseased brood at lower stimulus levels than non-hygienic bees (Masterman et al., 2001). In addition, hygienic bees can discriminate between the odors of healthy and diseased brood at lower stimulus levels than non-hygienic bees. This ability to discriminate is important in ensuring that the bees uncap and remove only diseased brood and not healthy brood. Gramacho and Spivak (2003) studied the differences in olfactory sensitivity and behavioral responses among honey bees bred for hygienic behavior. They hypothesized that within a colony bred for hygienic behavior, there are differences in olfactory sensitivity among bees of the same age. They predicted that bees that initiate the behavior by perforating an uncapping brood would have a greater olfactory sensitivity to the odor of the diseased brood, compared to bees that complete the behavior by removing the uncapped brood from the cells. They also predicted that the initiation of hygienic behavior depends on the olfactory sensitivity of the bee and the stimulus intensity of the abnormal brood. Differential olfactory sensitivity and responsiveness among hygienic bees could be the reason for the apparent partitioning of hygienic behavior into uncapping and removal components.

In our experiment, the grouped cells (about 50 brood cells in one block) constitute a concentrated area of perforated worker brood cells that probably results in a higher concentration of body fluid liberated per area than that liberated by the isolated cells ( 50 brood cells dispersed randomly in the experimental comb). The isolated cells were more frequently cleaned than the grouped cells (Table 1), though variance analysis of the data showed no significant difference $(\mathrm{P}=0.1421)$. The Carniolan bees were also more hygienic than the Africanized bees, but the difference was not significant $(\mathrm{P}=0.0840)$. Based on variance analysis, there was no interaction between honey bee race and treatment $(\mathrm{P}=0.7431)$. 
Table 1. Mean \pm standard deviation (in \%) of hygienic behavior of three colonies each of Africanized and Carniolan honey bees, based on four repetitions of 100 perforated grouped and 100 isolated worker brood cells.

\begin{tabular}{lcccc}
\hline \multicolumn{2}{c}{ Grouped cells } & & \multicolumn{2}{c}{ Isolated cells } \\
\cline { 5 - 5 } Carniolan & Africanized & & Carniolan & Africanized \\
\hline $77.17 \pm 16.34$ & $71.83 \pm 16.92$ & $85.67 \pm 9.37$ & $78.50 \pm 7.12$ \\
\hline
\end{tabular}

We conclude that honey bees can detect and remove both isolated and grouped dead brood. Hygienic behavior (Figure 3) appears to be more efficient in response to grouped than isolated damaged brood cells, which would be explained by the hypothesis of a greater concentration of volatiles released from the damaged pupae; however, additional research will be needed to determine if this hypothesis is correct.

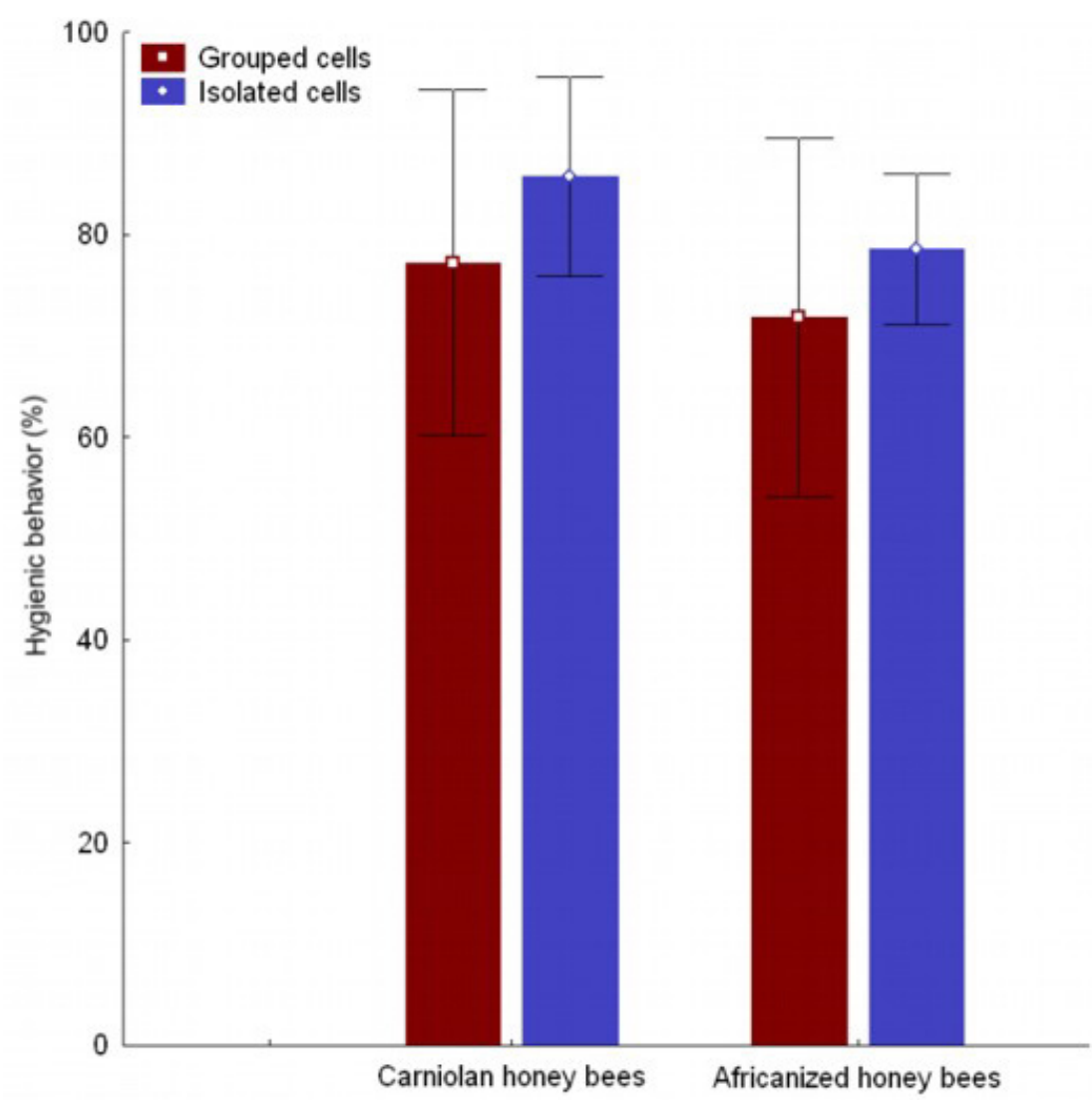

Figure 3. Mean \pm standard deviation (in \%) of the hygienic behavior of three colonies of Africanized honey bees and three colonies of Carniolan honey bees, with four repetitions of grouped brood cells and isolated brood cells. 


\section{ACKNOWLEDGMENTS}

The authors are grateful for the support given by the Department of Genetics (FMRPUSP, Ribeirão Preto, SP, Brazil) for the facilities to carry out the experiment and CAPES/MEC (Probral Project \#030/95) for financial support. We thank Dr. Peter Rosenkranz of the Institut fur Bienenkunde in Hohenheim, Germany, for suggestions and for providing the Carniolan queens. Our special thanks to Dr. Uilson Lopes and Dr. Karina Gramacho for the statistical analysis, to Dr. David De Jong for the revision of this paper and to the technicians João José dos Santos and Luis Aguiar for the beekeeping assistance.

\section{REFERENCES}

Gilliam M, Taber S III and Richardson GV (1983). Hygienic behavior of honey bees in relation to chalkbrood disease. Apidologie 14: 29-39.

Gilliam M, Taber III S, Lorenz BJ and Prest DB (1989). Hygienic Honeybees and Antagonistic Normal Microflora for Control of Chalkbrood Disease. In: Proceedings of the 32th International Apicultural Congress of Apimondia, October 22-28, Rio de Janeiro, 277.

Gramacho KP (1995). Estudo do Comportamento Higiênico em Apis mellifera, como Subsídio a Programas de Seleção e Melhoramento Genético em Abelhas. Master's thesis, Faculdade de Filosofia, Ciências e Letras de Ribeirão Preto, Universidade de São Paulo, Ribeirão Preto.

Gramacho KP (1999). Fatores que Interferem no Comportamento Higiênico das Abelhas Apis mellifera. Doctoral thesis, Faculdade de Filosofia, Ciências e Letras de Ribeirão Preto, Universidade de São Paulo, Ribeirão Preto.

Gramacho KP (2004). Sensorial Perception of Hygienic Honey Bee (Hartfelder KH, De Jong D, Pereira RA, dos Santos Cristino A, et al., eds.). Proceedings of the 8th IBRA International Conference on Tropical Bees and VI Encontro sobre Abelhas, Ribeirão Preto, Brasil, September 6-10, 2004, Ribeirão Preto.

Gramacho KP and Gonçalves LS (1994). Estudo Comparativo dos Métodos de Congelamento e Perfuração de Crias para Avaliação do Comportamento Higiênico em Abelhas Africanizadas. In: Anais do IV Congreso Iberolatinoamericano de Apicultura, Rio Cuarto-Córdoba, 45.

Gramacho KP and Gonçalves LSA (1996). A comparative Study of Hygienic Behavior in Several Honey Bee Races. In: Proceedings of 20th International Congress of Entomology, Firenze, 445.

Gramacho KP and Spivak M (2003). Differences in olfactory sensitivity and behavioral responses among honey bees bred for hygienic behavior. Behav. Ecol. Sociobiol. 54: 472-479.

Gramacho KP, Gonçalves LS and Rosenkranz P (1998). Study of the temperature of brood killed by the pin-killing method in worker bees of Apis mellifera carnica. Apiacta 33: 33-41.

Gramacho KP, Gonçalves LS, Rosenkranz P and De Jong D (1999). Influence of body fluid from pin-killed honey bee pupae on hygienic behavior. Apidologie 30: 367-374.

Masterman R, Ross R, Mesce K and Spivak M (2001). Olfactory and behavioral response thresholds to odors of diseased brood differ between hygienic and non-hygienic honey bees (Apis mellifera L.). J. Comp. Physiol. A 187: 441-452.

Message D (1979). Efeito de Condições Ambientais no Comportamento Higiênico em Abelhas Africanizadas Apis mellifera. Master's thesis, Faculdade de Medicina de Ribeirão Preto, Universidade de São Paulo, Ribeirão Preto.

Message D and Gonçalves LS (1980). Efeito das Condições Climáticas e da Colônia no Comportamento Higiênico em Abelhas Apis mellifera (Africanizadas). In: Anais do V Congresso Brasileiro de Apicultura, 3 Congresso Latinoiberoamericano de Apicultura, Viçosa, 140-147.

Milne CP Jr (1983). Laboratory measurement of honeybee brood disease resistance. 1. Uncapping of freeze killed and live brood by newly emerged workers in cages. J. Apic. Res. 21: 111-114.

Milne CP Jr (1983a). Honey bee (Hymenoptera: Apidae) hygienic behaviour and resistance to chalkbrood. Ann. Entomol. Soc. Am. 76: 384-387.

Milne CP Jr (1983b). Laboratory measurement of honeybee brood disease resistance. 2. Uncapping of freeze killed and live brood by newly emerged workers in cages. J. Apic. Res. 22: 115-118.

Milne CP Jr (1985a). Laboratory tests of honey bee hygienic behavior and resistance to European foulbrood. Am. Bee J. 125: 578-580.

Milne CP Jr (1985b). Estimates of the heritabilities of and genetic correlation between two components of honey bee 
(Hymenoptera: Apidae) hygienic behavior: uncapping and removing. Ann. Entomol. Soc. Am. 78: 841-844.

Newton DC and Ostasiewski NJA (1986). A simplified bioassay for behavioral resistance to American foulbrood in honey bees (Apis mellifera L). Am. Bee J. 126: 278-281.

Rothenbuhler WC (1964a). Behavior genetics of nest cleaning in honey bees. IV. Responses of F1 and backcross generations to disease-killed brood. Am. Zool. 4: 111-123.

Rothenbuhler WC (1964b). Behavior genetics of nest cleaning in honey bees. I. Responses of four inbreed lines to diseasekilled brood. Anim. Behav. 12: 578-583.

SAS Institute (1995). GLM procedure user's manual, release 6.10. SAS Institute Inc., Cary.

Spivak M and Gilliam M (1993). Facultative expression of hygienic behaviour of honey bees in relation to disease resistance. J. Apic. Res. 32: 147-157.

Spivak M and Downey D (1998). Field assays for hygienic behavior in honey bees (Hymenoptera: Apidae). J. Econ. Entomol. 91: 64-70.

Trump RF, Thompson VC and Rothenbuhler WC (1967). Behaviour genetics of nest cleaning in honeybees. V. Effect of previous experience and composition of mixed colonies on response to disease-killed brood. J. Apic. Res. 6: 127-131. 